Bond University

Research Repository

\title{
Psychological status of former refugee detainees from the Woomera Detention Centre now living in the Australian community
}

Sobhanian, Farahnaz; Boyle, Gregory J.; Bahr, Mark; Fallo, Tindaro

Published in:

Psychiatry, Psychology and Law

DOI:

10.1375/pplt.13.2.151

Licence:

Other

Link to output in Bond University research repository.

Recommended citation(APA):

Sobhanian, F., Boyle, G. J., Bahr, M., \& Fallo, T. (2006). Psychological status of former refugee detainees from the Woomera Detention Centre now living in the Australian community. Psychiatry, Psychology and Law, 13(2), 151-159. https://doi.org/10.1375/pplt.13.2.151

\section{General rights}

Copyright and moral rights for the publications made accessible in the public portal are retained by the authors and/or other copyright owners and it is a condition of accessing publications that users recognise and abide by the legal requirements associated with these rights.

For more information, or if you believe that this document breaches copyright, please contact the Bond University research repository coordinator. 


\section{Bond University}

\section{ePublications@bond}

$1-1-2006$

\section{Psychological status of former refugee detainees from the Woomera Detention Centre now living in the Australian community.}

Farahnaz Sobhanian

Bond University

Gregory J. Boyle

Bond University, Gregory_Boyle@bond.edu.au

Mark Bahr

Bond University, Mark_Bahr@bond.edu.au

Tindaro Fallo

Follow this and additional works at: http://epublications.bond.edu.au/hss_pubs

Part of the Psychology Commons

\section{Recommended Citation}

Farahnaz Sobhanian, Gregory J. Boyle, Mark Bahr, and Tindaro Fallo. (2006) "Psychological status of former refugee detainees from the Woomera Detention Centre now living in the Australian community." „, .

http://epublications.bond.edu.au/hss_pubs/227

This Journal Article is brought to you by the Faculty of Humanities and Social Sciences at ePublications@bond. It has been accepted for inclusion in Humanities \& Social Sciences papers by an authorized administrator of ePublications@bond. For more information, please contact Bond University's 
Word Count: 4628

\title{
Psychological Status of Former Refugee Detainees from the Woomera Detention Centre now Living in the Australian Community
}

\author{
Farahnaz Sobhanian, Gregory J. Boyle ${ }^{1}$ and Mark Bahr \\ Bond University
}

and

Tindaro Fallo

Migrant Health Service, Adelaide

\footnotetext{
${ }^{1}$ Corresponding author:
}

Gregory J. Boyle, PhD., Faculty of Humanities and Social Sciences, Bond University, Gold Coast, Queensland 4229.

Tel. 07 5595-2525

Fax: 07 5595-2545

Email: gregb@bond.edu.au 


\begin{abstract}
The impact of detention on psychological status, and quality of life was examined in a sample of 150 former refugee detainees from the Woomera Detention Centre now living in the Australian community. Detainees completed a Psychological status inventory including the Truncated Firestone Assessment of Self-destructive Thoughts (T-FAST),the Quality of Life Inventory, the Suicidal Ideation Scale, and the Profile of Mood States,. Former detainees reported their current status; and retrospectively reported their status while detained.

The psychological health of refugee detainees improved significantly following their release into the Australian community. Self-reported levels of suicidal ideation, self-destructive thoughts and negative mood states were elevated significantly and quality of life was significantly reduced while being held in detention as compared with when the asylum seekers were living in the broader community. Mandatory incarceration in Australian detention centres of refugees appears to contribute to severe psychological distress.
\end{abstract}

Key Words: Psychological status; Former refugee detainees; Woomera Detention Centre; Suicidal ideation; Self-destructive thoughts. 


\section{Psychological Status of Former Refugee Detainees from the}

\section{Woomera Detention Centre now Living in the Australian}

\section{Community.}

During the past decade, the number of refugees has increased exponentially (Peteri, 2000). Millions of people, often fearing for their lives, and/or to escape persecution or torture, have been forced to flee their homelands and assume refugee status in a new country, or become displaced persons (Eisenbruch,1991) . Fazel and Silove (2006) report that more than 7 million refugees are currently confined in “warehouse” facilities.

Refugees are a very vulnerable group not only as a consequence of their suffering of violence, war, or persecution in their home country, but also because despite this, they lack the protection of any government, and are often subjected to further violence and victimisation (Harrell-Bond,1986; Keyes, 2000). Refugees have also been reported to suffer from a range of mental health problems including PTSD(Mollica, Poole, \& Tor, 1998).

In recent times refugee detention centres have been increasingly used as a mechanism for handling the disposessed. As such Refugees often face forced incarceration in a refugee detention centre within their host country. According to Loff (p. 792) “Australia places many asylum seekers, most of whom have suffered past trauma, including torture, in open-ended terms of detention. Terms of 4 years or more are not uncommon. Children are not exempt from such treatment....”. The incarceration of innocent people shows both a distinct lack of compassion and is a clear violation of basic human rights (Healey, 2002; Mares, 2002; McMaster, 2001)). Keller et al. (p. 1721) note that, refugees arriving in Australia (as in the USA) "are 
likely to be held in detention for months or years pending adjudication of their asylum claims”. The impact of detention itself compounds the adverse psychological effects of earlier, often traumatic, experiences under inhumane regimes (Loff, B., Snell, B., Creati, M., \& Mohan, M., 2002). Former detainees have reported feeling dehumanised by their treatment in Australian detention centres. For example, as Loff (2002, p. 792) pointed out, “detainees may be called by number not name, and are subject to line-ups, head counts, and room searches, often at night”. Detainees commonly lack the opportunity to undertake meaningful activities(Loff, 2002). The boredom and frustration resulting from prolonged detention together with social isolation may be responsible for the outbreaks of violence, including domestic violence among detainees and between detainees and officials (Human Rights and Equal Opportunity Commission., 1998). The Human Rights and Equal Opportunity Commission went further on February 6, 2002, and stated that the Woomera Detention Centre was in breach of several articles of the Convention on the Rights of the Child, which had been ratified by Australia in 1990. The potential for deleterious effects of prolonged detention on the mental health of asylum seekers has been raised repeatedly (Sabin, Sabin, Kim, Vergara \& Varese, 2006; Porter \& Haslam, 2005; Barnes, 2003).

Loff (p. 792) further notes that, “There have been continuing acts of self-injury, hunger strikes, and attempted suicide...asylum seekers have sewn their lips together to draw attention to the hopelessness of their situation.” Sultan and O'Sullivan(2001) reported that "a number of children have displayed profound symptoms of psychological distress, including mutism, stereotypic behaviours, and refusal to eat or drink”. Refugees may suffer a loss in self-confidence, and security, as a result of the loss of their homeland, and loss of their social and cultural environment which had 
been emotionally structured over a long period of time (Loff, Snell, Creati, \& Mohan, 2002).

Keller et al. (2003) reported that refugee detainees exhibited significantly elevated levels of anxiety (77\%), depression (86\%), and PTSD (50\%), all of which correlated significantly with duration of detention. They also reported that "participants who had been released had marked reductions in all psychological symptoms, but those still detained were more distressed than at baseline...detention of asylum seekers exacerbates psychological symptoms” (p. 1721). Similar patterns of depression, Anxiety, and post-traumatic disorders are being reported of refugees in detention across the world (Savin, Seymour, Littleford, Bettridge \& Giese, 2005). According to Silove, Steel, and Mollica (2001, p. 1437), "Psychological distress among inmates is reflected in suicide attempts, acts of mass violence, group breakouts, rioting, burning of facilities, and sporadic hunger strikes”. Furthermore, refugee detainees have "reported greater exposure to torture and other forms of persecution in their home country, ... much higher levels of depression, panic, posttraumatic stress symptoms, somatic distress, and suicidal urges...” as compared with refugees living in the Australian community.

In October 1999, the Australian Federal Government introduced legislation requiring the issuing of three-year temporary protection visas (TPVs) for asylum seekers classified as refugees, having arrived in Australia without proper documentation(Steel, 2003). The new TPVs also introduced a number of restrictions on the entitlements available to refugees such as access to Commonwealth funded English language training, housing support or employment assistance, and with access to professional or vocational training being charged at overseas students' rates. TPV holders cannot leave and re-enter Australia and are not allowed family reunion(Steel, 
2003). Refugees placed on TPVs were significantly more psychologically distressed in comparison with refugees and migrants who had permanent residency status (Steel, \& Silove, 2001).

The present study examines three major hypotheses:

H1: Reported negative mood states, suicidal ideation and self-destructive thoughts will be significantly elevated among former refugee detainees relating to when they were detained as compared with when they were living in the Australian community.

H2: Reported negative mood states, suicidal ideation and self-destructive thoughts will be directly related to length of detention.

H3: Significantly more male former refugee detainees will report suicidal ideation and self-destructive thoughts than female former refugee detainees in relation to when they were in detention.

\section{Method}

\section{Participants}

Some 150 former refugee detainees (104 male; 46 female) from the Woomera Detention Centre now living in the Australian community participated in this study. Asylum seekers who had arrived from Iran and Afghanistan, ranged in age from 18 to 70 years, with the mean age being 31.75 years ( $S D=9.21$ years). Length of time in the detention centre ranged from two months to 21 months and the mean time period was 11.30 months ( $\mathrm{SD}=3.80$ months). Length of time living in the community ranged from one month to 20 months with the mean time period being 6.97 months $(S D=4.10$ months). The number of children of former detainees ranged from zero to six and the 
mean was 1.81 children ( $\mathrm{SD}=1.85$ children). Education level ranged from one to 16 years with the mean being 6.61 years $(S D=4.00$ years).

\section{Instruments}

Four different self-report questionnaires were used in order to measure selfdestructive thoughts, quality of life, mood states, and suicidal ideation of refugees. Each of the questionnaires was translated from English into Farsi, and subsequently backtranslated to English by an independent language translation service in Sydney, in order to ensure the validity of the translations.

The Truncated Firestone Assessment of Self destructive Thoughts was devised to assess refugees self-destructive thoughts. Firestone, \& Firestone (1996) developed a self report instrument consisting of 84 items measuring 11 facets of self destructive ideation. The Firestone Assessment of Self destructive Thoughts' (FAST) measures 11 types of self-destructive thinking these are self-depreciating thoughts, self-denying thoughts, cynical attitudes, isolating thoughts, self-contempt, thoughts supporting addictions, hopelessness, giving up, self-harm, suicide plans, and suicide injunctions. Respondents endorse items on a five-point scale from Never to Most of the time. It is a measure of negative thoughts and attitudes that are said to be at the core of maladaptive behaviour. Cronbach’s alpha coefficients ranging from .76 to .91 have been reported for the 11 subscales of the FAST (Martin, 2001)., suggesting moderate item homogeneity(Boyle, 1991).

Due to constraints on the study placed by the university ethics committee it was not possible to administer the complete FAST scale, subsequently a brief 11 item scale was devised that tapped each of 11 sub-domains of the FAST. The resultant 11 item scale (T-FAST) had comparable internal consistency to that reported for the 
parent instrument. Cronbach’s alpha for the instrument during detention was .85, and .79 whilst in the community $(\mathrm{n}=150)$. Item total correlations ranged from .48 to .75 for time in detention and from .15 to .63 for time in the community. The presence of low item total correlations at time two indicate that scale reliability can be improved by item deletion, however this would be at the cost of domain coverage and hence content validity as such all items are used in the analysis. Test stability was moderate with the correlation between detention scores and community based scores being slightly less than $.5(\mathrm{r}=.46)$.

Given the lack of strong psychometric data for the fast there is no great loss of utility in using the truncated measure. In interpreting the FAST one should be aware that, FAST content domains arise from a small $(n=21)$ restricted focus group of persons receiving 'voice therapy.' Second, the FAST is closely anchored to a theoretical orientation known as ‘concept of the voice’ in which additional studies are needed to validate the FAST items (Martin, 2001). That said the FAST and T-FAST domains are similar in many ways to other depression and suicide inventories such as the Beck Suicide Inventory (Beck, 1991; Reinehr, 2001). Total scores tend to be higher for respondents in diagnostic groups than for non-clinical respondents, and within diagnostic groups, suicide ideators score more highly than do non-ideators (Reinehr, 2001).

The Quality of Life Inventory (QOLI) — (Frisch, 1994). is a brief measure of life satisfaction. It measures weighted satisfaction in each of 16 designated life areas by means of two questions for each area. The subscales of the QOLI are labelled: health, self-esteem, goals and values, money, work, play, learning, creativity, helping, love, friends, children, relatives, home, neighbourhood, and community. Clients are asked first to rate their level of satisfaction (+3) for an area and then to indicate the 
relative importance $(0,1$, or 2$)$ that they place on that area. Satisfaction scores are multiplied by importance scores to obtain a total of 16 weighted satisfaction scores (ranging from -6 to +6 ) which are then added together to produce the QOLI total scores.

The QOLI has been standardized on a national sample that roughly matches the 1992 U.S. census in regard to the distribution of racial and ethnic groups but its match on other relevant characteristics cannot be determined from the manual (Barnes, 2003).]. The overall Cronbach alpha coefficient for the QOLI was reported as being .70 ( Barnes, 2001) indicating moderate item homogeneity (Boyle, 1991; Johnson, 2001). .

The Profile of Mood States (POMS)—(McNair, Lorr, \& Droppleman, 1981). is a self-report measure which can be administered individually or in groups. The overall Cronbach alpha coefficient for the POMS is .90 (McNair, Lorr, \& Droppleman, 1981). The POMS assesses six affective or emotional dimensions; tension-anxiety, depression-dejection, anger-hostility, vigour-activity, fatigue-inertia, and confusion-bewilderment.

The Suicidal Ideation Scale (SIS) was developed by Rudd(1989,1990). The SIS comprises two sections: 1) Biographical data, and 2) A suicidal ideation questionnaire, which comprises 10 items and only one subscale (suicidal ideation). Each item is assessed on a five point scale, ranging from never or none of the time (0) to always or a great many times (4). Ten questions comprised the SIS, ranging from "I feel that life isn’t worth living” to "I have made attempts to kill myself." The overall Cronbach alpha coefficient for the SIS scale was 0.88. Item total correlations ranged from .50 to .73 (Klayish, 1992). 


\section{Procedure}

Testing was carried out in a room of the Migrant Health Centre in Adelaide under the supervision of a clinical psychologist. The tests were administered either on an individual basis or a small group basis. The former refugee detainees were asked to sign an informed consent form, which was written in their mother language (Farsi). They were told that they could withdraw from the study at any time they wished to do so. The testing session took 20 minutes. Participants were asked to answer each question twice based on how (1) they felt when they were in the centre and (2) how they had been feeling since living in the community. Participants were debriefed after the testing by the psychologist in case they were distressed. There was also a 24 hour telephone number available to them if they felt any emotional distress after the testing.

\section{Results}

A 2(Detention status) x 2(Gender) x 10(Time in centre) MANOVA was run to investigate the three primary hypotheses. The dependent variables were the T-FAST item scores. The multivariate test of within subjects effects for the T-FAST subscales was significant $\left(\mathbf{F}(11,137)=87.25, p<.0001 ; \eta^{2}=.89\right)$, comparing the refugees' time in the detention centre with when they were living in the Australian community. Thus, there were significant differences in self-reported psychological functioning of the refugees between the two time periods. 
In analyzing the univariate results for the T-FAST subscales it can be seen that there were significant differences by detention status (living in the detention centre versus living in the community) for most of the T-FAST subscales (Table 1). Mean scores were significantly lower for the majority of T-FAST subscales after the asylum seekers had been released from the detention centre. In short their psychological status improved markedly after release into the Australian community.

Insert Figure 1 about here

There was also a significant main effect for time in detention centre $(F(11,86)=$ 98.74, $p<.001, \eta^{2}=.16$ ). Refer to Figures $1 \mathrm{a}$ and $\mathrm{b}$. Most notably the results indicate significant increases in detainees suicidal ideation with time in detention. Note the rapid increase in SIS score over the first 8 months in detention. After 8 months in detention males total SIS score exceeds 70 (Figure $1 \mathrm{~b}$ ). Female refugees appear to initially express more suicidal ideation than males but report lower overall totals (Figure 1 a). The main effect for gender $\left(\mathrm{F}(11,110)=5.45, p<.001, \eta^{2}=.08\right)$ is significant as hypothesised. The general pattern of change is the same for both males and females as is reflected in the lack of a significant time in detention by gender interaction $(F(121,880)=.94$, n.s. $)$. There was also a significant detention status by gender interaction $\left(\mathrm{F}(187,110)=4.572, p<.001, \eta^{2}=.31\right)$. It is apparent from Figure 2 that typically male refugees showed greater evidence of self-destructive ideation than did female refugees, and that they had higher T-FAST scores on release than did female refugees. Power of all statistical tests approached 1.00. 
Insert Figure 2 about here

Insert Table 2 about here

The overall test of multivariate within subjects effects for the QOLI subscales was significant $(\mathrm{F}(16,122)=10.12, p<.0001)$. A comparison of the means in Table 2 show a marked increase in mean scores across the QOLI scales between time in detention centre and subsequent release into the community. It is clear that the former refugee detainees were significantly less satisfied with different aspects of their life while they were detained and displayed more satisfaction with the quality of their life after being released. The effect size statistic indicates that the change in QOLI scores between the two time periods was moderately large.

\section{Insert Table 3 about here}

There was a significant multivariate within subjects effect of detention on mood state $(\mathrm{F}(6,139)=43.74, p<.0001)$. Table 3 shows significant decreases in negative mood states and a corresponding increase in respondents Vigour scores. Univariate within subjects' ANOVA results revealed significant differences for all six of the POMS scales $(p<.0001)$, indicating that there were significant improvements in refugees' mood states after they had been released into the Australian community.

There was a significant multivariate within subjects effect of detention on Suicidal Ideation scores $(\mathrm{F}(1,41)=926.41, p<.0001)$. Mean score for suicidal ideation was significantly higher while the refugees were in the detention centre than 
when living in the Australian community $(\mathrm{M}=67.81$, sd. $=7.24$, \& $\mathrm{M}=20.34$, sd= 7.39 respectively). This result was marked by a very large effect $\operatorname{size}\left(\eta^{2}=.96\right)$ indicating that there was a major reduction in suicidal ideation following release of the refugees into the community.

\section{Discussion}

Refugees suffer from various psychological problems such as depression, anxiety, grief, Posttraumatic Stress Disorder (PTSD), and helplessness (Kroll, Habenicht, Mackenzie, Yang, Chang, Vang, Nguyen, Ly, Phommasouvanh, Nguyen, Vang, Souvannasoth, \& Cabugao, 1989, Van Willigen, 1993; Westremeyer, 1989).. After leaving their homeland and arriving in a host country sometimes refugees are detained in refugee camps. Living in refugee camps creates additional psychological distress for refugees(Loff, Snell, Creati, \& Mohan, 2002).. The Human Rights and Equal Opportunity Commission in Australia ( Human Rights and Equal Opportunity Commission., 1998) has suggested that boredom and frustration resulting from detention, together with social isolation may be responsible for outbreaks of violence in detention centres. The present study investigated the effects of being detained on the psychological functioning of 150 former refugee detainees from Woomera detention centre who were now living in the Australian community.

Measuring the level of self-destructive thoughts of refugees revealed that there are significant differences between the two time periods (living in the detention centre versus living in the Australian community) in relation to self-harm and suicidal thoughts. The results suggested that the psychological states of refugees improved significantly after their release from the Woomera Detention Centre into the 
Australian community. Also, the results suggested that there was a significant reduction in suicidal ideation after refugees had left the detention centre. Evidently, former refugees report significantly improved psychological functioning after their release into the community.

The present findings are in accord with those of the Human Rights and Equal Opportunity Commission’s report in Australia(Human Rights and Equal Opportunity Commission., 1998) which reported that asylum seekers suffer from significantly higher levels of depression, suicidal ideation, PTSD, anxiety, and panic as compared with their compatriot asylum seekers, refugees, and immigrants living in the community. The present findings also suggest that the former refugee detainees are more satisfied with their quality of life when living in the community than when they were detained.

In addition, there was a significant improvement in refugees' moods after their release into the Australian community. The former refugee detainees reported significantly less tension, depression, and anger (as measured via the POMS) after living in the community. Steel and Silove(2001) also suggested that long-term detention is a source of frustration, despondency and depression often resulting in drastic action being taken by detainees. Their report highlighted the negative psychological impact of prolonged detention, pointing out that those who had been in the Woomera detention centre for three or four weeks, for example, were notably less tense and depressed than those who had been detained for a year or more (Steel, \& Silove, 2001).It was also hypothesised that significantly more male former refugee detainees would report suicidal ideation and self-destructive thoughts than female former refugee detainees in relation to when they were in detention. However, the 
present findings did not find significant sex differences between the asylum seekers in relation to self-harm and suicidal ideation.

In summary, the results from this study suggest that former refugee detainees from the Woomera Detention Centre manifest significantly improved psychological functioning when living in the Australian community as compared with when they were confined to the detention centre. However, the results do not suggest a direct correlation between length of detention and psychological functioning. Also, the results do not show any differences between male and female former refugees in relation to self-harm and suicidal ideation. 


\section{References}

Barnes, D. (2003). (Ed.), Asylum seekers and refugees in Australia: Issues of mental health and wellbeing. Parramatta, NSW: Transcultural Mental Health Centre.

Barnes, L. B. (2001). Review of the Quality of Life Inventory. In B. S. Plake \& J. C. Impara (Eds.), The fourteenth mental measurements yearbook (pp.974-975). Lincoln, Nebraska: University of Nebraska Press.

Beck, A. (1991). Beck Suicide Inventory. San Antonio, TX: Psychological Corporation.

Boyle, G. J. (1991). Does item homogeneity indicate internal consistency or item redundancy in psychometric scales? Personality and Individual Differences, 12, 291-294.

Boyle, G. J., \& Langley, P. D. (1989). Elementary statistical methods for students of psychology, education and the social sciences. Sydney: Pergammon.

Boyle, G. J. (1987). A cross-validation of the factor structure of the Profile of Mood States: Were the factors correctly identified in the first instance? Psychological $\underline{\text { Reports, }}$ 60, 343-354.

Eisenbruch M. (1991) From posttraumatic stress disorder to cultural bereavement: Diagnosis of Southeast Asian refugees. Social Science Medicine, 33, 673- 680.

Fazel, M. \& Silove, D. (2006) Detention of Refugees, British Medical Journal, $\underline{332}$, 251-252.

Frisch, M. B. (1994). Quality of life inventory: Manual and treatment guide. United States of America: National computer systems.

Firestone, R.W., \& Firestone, L. A. (1996). Firestone Assessment of Self-Destructive Thoughts manual. San Antonio, TX: Psychological Corporation. 
Harrell-Bond, B. (1986). The refugee crisis: British and Canadian responses. $\underline{\text { Paper }}$ presented at the international symposium of the refugee studies programme. Oxford, UK: Oxford University.

Healey, J. (2002). (Ed.), Australia’s immigration debate. Rozelle, NSW: Spinney Press.

Human Rights and Equal Opportunity Commission. (1998). Those who've come across the seas: The report of the Commission's inquires into the detention of unauthorised arrivals. Canberra, ACT: Commonwealth of Australia.

Johnson, R. W. (2001). Review of the Quality of Life Inventory. In B. S. Plake \& J. C. Impara (Eds.), The fourteenth mental measurements yearbook (pp.974-975). Lincoln, Nebraska: University of Nebraska Press.

Keller, A. S. et al. (2003). Mental health of detained asylum seekers. The Lancet, 362, 1721-1723.

Keyes, E., F. (2000). Mental health status in refugees: An integrated review of current research. Issues in Mental Health Nursing, 21, 397- 410.

Klayish, M. (1992). An investigation into psychometric properties of the suicidal ideation scale: A hierarchical-cumulative model of suicide ideation. Unpublished Honours thesis, Department of Psychology, University of Queensland.

Kroll, J., Habenicht, M., Mackenzie, M. D., Yang, M., Chan, S., Vang, T., Nguyen, T., Ly, M., Phommasouvanh, R., Nguyen, H., Vang, Y., Souvannasoth, L., \& Cabugao, R (1989). Depression and posttraumatic stress disorder in Southeast Asian refugees. American Journal of Psychiatry, 146, 1592-1597.

Loff, B. (2002). Detention of asylum seekers in Australia. The Lancet, 359, 792-793. 
Loff, B., Snell, B., Creati, M., \& Mohan, M. (2002). “Inside” Australia’s Woomera Detention Centre, The Lancet, 359, 683.

Lustig, S.L., Kia-Keating, M., Grant-Knight, W., Geltman, P., Ellis, H., Birman, D. Kinzie, D., Keane, T., \& Saxe, G.N. (2003) Review of Child and Adolescent

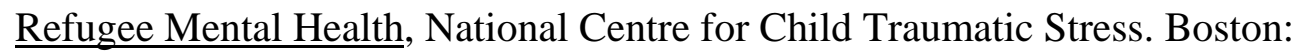
Massachusetts.

Mares, P. (2002). Borderline: Australia's response to refugees and asylum seekers in the wake of the Tampa. Sydney: University of New South Wales Press.

Martin, W. E. (2001). Review of the Firestone assessment of self-destructive thoughts. In S. P. Bararas \& J. C. Impara (Eds.), The fourteenth mental measurements yearbook (pp. 491-493). Lincoln, Nebraska: University of Nebraska Press.

McMaster, D. (2001). Asylum seekers: Australia's response to refugees. Melbourne: Melbourne University Press.

McNair, D., M., Lorr, M., \& Droppleman, L., F. (1981). Profile of mood states manual. San Diego, CA: Educational and Industrial Testing Service.

Mollica, R.F., Poole, C., \& Tor, S. (1998). Symptoms, functioning and health of a massively traumatized population. In P. B. Dohrenwend (Ed.), Adverse psychopathology. New York: Oxford University Press.

Peteri, M. (2000). Forced displacement: refugee trauma, protection and assistance. In Danieli Y., Rodney, N., \& Weisoeth, L. (Eds.), International responses to traumatic stress. New York: United Nations Publications. 
Peterson, R. A., \& Headen, S. W. (1995). Profile of mood states. In D. J. Keyser \& R. C. Sweetland. Test critiques, Vol. 1 (pp.522-529). Austin, TX.: Test Corporation of America.

Porter, M. \& Haslam, N. (2005) Predisplacement and Postdisplacement Factors Associated with Mental Health of Refugees and Internally displaced Persons, Journal of the American Medical Association, 294(5), 602-612.

Reinehr, R. C. (2001). Review of the Firestone Assessment of Self-destructive Thoughts. In S. P. Bararas \& J. C. Impara (Eds.), The fourteenth mental measurements yearbook (pp. 491-493). Lincoln, Nebraska: University of Nebraska Press

Rudd, M., D. (1990). An integrative model of suicidal ideation. Suicide and LifeThreatening Behaviour, 20, 16-30.

Rudd, M., D. (1989). The prevalence of suicidal ideation. Suicide and LifeThreatening Behaviour, 19, 173-183.

Sabin, M., Sabin, K., Kim, H.Y., Vergana, M. \& Varese, L. (2006) The mental health status of Mayan refugees after repatriation to Guatemala, Pan American Journal of Public Health, 19(3), 163-171.

Savin, D., Seymour, D.J., Littleford, L.N., Bettridge, J. \& Giese, A. (2005) Findings from Mental Health Screening of Newly Arrived Refugees in Colorado, Public Health Reports, 120, 224-229.

Silove, D., Steel, Z., \& Mollica, R. F. (2001). Detention of asylum seekers: Assault on health, human rights, and social development. The Lancet, 357, 1436-1437. 
Steel, Z. (2003). The politics of exclusion and denial: The mental health costs of Australia's refugee policy. $38^{\text {th }}$ Congress, Royal Australian and New Zealand College of Psychiatrists: Hobart.

Steel, Z., \& Silove, D.M. (2001). The mental health implications of detaining asylum seekers. Medical Journal of Australia, 175, 596-599.

Sultan, A., \& O’Sullivan, K. (2001). Psychological disturbances in asylum seekers held in long term detention: A participant-observer account. Medical Journal of Australia, $\underline{175}, 593-596$.

Van Willigen, L. (1993). Psyische problemen door uitzichtloosheid onder vluchtelingen. Het Nieuwsblad, 5, 31.

Westremeyer, J. (1989). Mental health for refugees and other migrants: Social and preventive approaches. Springfield, IL: Thomas. 
Table 1: Mean T-FAST scores for refugees by detention status (in Woomera Detention Centre vs. in the Australian Community) *

\begin{tabular}{|c|c|c|c|c|}
\hline Subscales $^{2}$ & $\begin{array}{c}\text { Centre } \\
\mathbf{M}\end{array}$ & $\begin{array}{c}\text { Community } \\
\mathbf{M}\end{array}$ & $F_{(1,110)}$ & $\begin{array}{c}\text { Effect Size } \\
\left(\text { Eta }^{2)}\right.\end{array}$ \\
\hline Self-depreciation & 58.64 & 22.94 & $444.56 * * *$ & .78 \\
\hline Self-denial & 50.42 & 16.23 & $401.71^{* * *}$ & .77 \\
\hline Cynical attitude & 60.43 & 41.19 & $173.14 * * *$ & .59 \\
\hline Isolation & 58.63 & 31.11 & $232.77 * * *$ & .66 \\
\hline Self-contempt & 52.46 & 22.68 & $352.48 * * *$ & .75 \\
\hline Addiction & 72.77 & 66.61 & $36.32 * * *$ & .23 \\
\hline Hopelessness & 91.95 & 85.01 & $44.79 * * *$ & .27 \\
\hline Giving up & 76.79 & 58.06 & $132.12 * * *$ & .52 \\
\hline Self- harm & 74.49 & 57.64 & $235.79 * * *$ & .66 \\
\hline \multirow{2}{*}{$\begin{array}{l}\text { Planning suicide } \\
\text { Carrying-out suicide }\end{array}$} & 73.45 & 60.65 & $183.48 * * *$ & .61 \\
\hline & 63.18 & 53.38 & $78.31 * * *$ & .39 \\
\hline
\end{tabular}

*Note: Means are SPSS MANOVA harmonic marginal estimates.

${ }^{2}$ Note: All statistics are reported to two decimal places only (except for p- values), in line with Boyle and Langley (1989, pp. 40-46). 
Table 2: Mean Quality of Life Inventory (QOLI) scale scores by detention status (in Woomera Detention Centre vs. in the Australian Community).

\begin{tabular}{lcccc}
\hline \multicolumn{1}{c}{ Subscales } & $\begin{array}{c}\text { Centre } \\
\mathbf{M}\end{array}$ & $\begin{array}{c}\text { Community } \\
\mathbf{M}\end{array}$ & $\mathbf{F}_{(\mathbf{1}, 137)}$ & $\begin{array}{c}\text { Effect Size } \\
\left(\mathbf{E t a}^{2}\right)\end{array}$ \\
\hline Health & 13.18 & 60.46 & $17.85^{* * *}$ & .11 \\
Self- esteem & 10.05 & 48.14 & $14.67^{* * *}$ & .09 \\
Goals & 6.68 & 48.73 & $27.32^{* * *}$ & .16 \\
Money & 4.34 & 31.94 & $15.95^{* * *}$ & .10 \\
Work & 2.81 & 32.68 & $26.66^{* * *}$ & .16 \\
Play & 2.30 & 60.30 & $46.90^{* * *}$ & .25 \\
Learning & 5.04 & 38.16 & $8.92^{* *}$ & .06 \\
Creativity & 5.32 & 35.50 & $25.01^{* * *}$ & .15 \\
Helping & 26.94 & 27.45 & 2.09 & .01 \\
Love & 9.62 & 56.62 & $20.41^{* * *}$ & .13 \\
Friends & 1.89 & 67.11 & $4.48^{*}$ & .03 \\
Children & 41.57 & 59.72 & $10.91^{* *}$ & .07 \\
Relative & 12.09 & 44.11 & $14.70^{* * *}$ & .09 \\
Home & 15.08 & 49.17 & $20.21^{* * *}$ & .12 \\
Neighbours & 1.81 & 76.80 & $4.94^{*}$ & .03 \\
Community & 33.43 & 93.42 & $93.79^{* * *}$ & .40 \\
\hline & & & & .03 \\
\hline
\end{tabular}


Table 3: Mean Profile of Mood States (POMS) subscale scores by detention status (in Woomera Detention Centre vs. in the Australian Community)

\begin{tabular}{|c|c|c|c|c|}
\hline Subscales & $\begin{array}{c}\text { Center } \\
\mathbf{M}\end{array}$ & $\begin{array}{c}\text { Community } \\
\mathbf{M} \\
\end{array}$ & $F_{(1,144)}$ & $\begin{array}{c}\text { Effect Size } \\
\left(\text { Eta }^{2)}\right.\end{array}$ \\
\hline Tension- Anxiety & 51.96 & 42.05 & $155.75^{* * *}$ & .34 \\
\hline $\begin{array}{l}\text { Depression- } \\
\text { Dejection }\end{array}$ & 56.21 & 42.37 & $181.01 * * *$ & .43 \\
\hline Anger- Hostility & 47.45 & 42.91 & $134.05 * * *$ & .31 \\
\hline Vigour & 51.39 & 56.74 & $53.39 * * *$ & .18 \\
\hline Fatigue & 58.75 & 44.27 & $56.84 * * *$ & .20 \\
\hline $\begin{array}{l}\text { Confusion- } \\
\text { Bewilderment }\end{array}$ & 52.86 & 48.18 & $131.93^{* * *}$ & .31 \\
\hline
\end{tabular}


Figure Captions

Figure 1: Total Suicide Ideation Score (SIS) and Truncated-Firestope Assessment of Self-destructive Thoughts (T-FAST) by time in Detention and Gender.

Figure 2: T-FAST Total scores by Detention Status and Gender. 